\title{
Selekcyjna funkcja południowoafrykańskiego systemu edukacji w czasach apartheidu (1948-1994)
}

\begin{abstract}
Abstrakt
Artykuł stanowi analizę selekcyjnej funkcji szkolnictwa w Republice Południowej Afryki w okresie apartheidu (1948-1994). Zawarto w nim rozważania dotyczące praktyk segregacji rasowej i roli szkolnictwa w odtwarzaniu zróżnicowania społecznego w południowoafrykańskiej edukacji. Analizy osadzone są w teoretycznych koncepcjach zamknięcia społecznego. Odnoszą się one do praktyk selekcyjnych oraz zjawisk dyskryminacji obecnych w kolejnych etapach rozwoju systemu edukacji w RPA.
\end{abstract}

Słowa kluczowe: Republika Południowej Afryki, edukacja, rasizm, zamknięcie społeczne, apartheid, dyskryminacja, nierówności.

\section{The selective function of the South African system of education in the Apartheid Era (1948-1994)}

\begin{abstract}
The article is an analysis of the selective function of education in South Africa during the apartheid period (1948-1994). It contains considerations regarding racial segregation practices and the role of education in reconstructing social diversity in South African education. The analyzes are based on theoretical concepts of social closure. They refer to selection practices and discrimination phenomena present in the consecutive stages of the development of the education system in South Africa.
\end{abstract}

Keywords: South Africa, education, racism, social closure, apartheid, segregation, discrimination, inequality.

\footnotetext{
* Uniwersytet Adama Mickiewicza w Poznaniu, Zakład Edukacji Wielokulturowej i Badań nad Nierównościami Społecznymi.
} 


\section{Wprowadzenie}

Współczesna myśl socjologiczna oferuje wiele podejść teoretycznych interpretujących mechanizmy prowadzące do powstawania nierówności społecznych (Turner 2004: 5). Równocześnie istnieje wiele teorii i koncepcji w ramach socjologii edukacji oraz pedagogiki wskazujących na istotną rolę szkolnictwa jako czynnika konstruującego nierówności we współczesnych społeczeństwach (Melosik 1995: 175). $\mathrm{Z}$ tej perspektywy edukacja - w swojej funkcji selekcyjnej i alokacyjnej - stanowi jeden z kluczowych czynników posiadających wpływ na działanie struktury społecznej. Szkoły - będąc w istocie instytucjami opartymi na wartościach grup dominujących - dokonują swoistej selekcji opartej na zasadach i celach wyznaczanych przez reprezentantów tych grup. Instytucjonalny system szkolnictwa funkcjonujący $\mathrm{w}$ takich uwarunkowaniach $\mathrm{z}$ jednej strony funkcjonalnie dostosowuje się do oczekiwań, a $\mathrm{z}$ drugiej jako podmiot bierze aktywny udział $\mathrm{w}$ sankcjonowaniu hierarchicznej struktury społecznej (Moore 2004: 18).

Artykuł stanowi wyraz zainteresowań badawczych autora zorientowanych wokół problematyki zróżnicowania społecznego i roli szkolnictwa w procesach stratyfikacji społecznej. Jego celem jest analiza wybranych kontekstów, dotyczących relacji pomiędzy edukacją, procesami selekcji i zjawiskami segregacji rasowej w Afryce Południowej w okresie apartheidu. W szczególności uwaga skupiona została na zagadnieniu selekcyjnej funkcji edukacji i jej konsekwencjom dla funkcjonowania zróżnicowanej rasowo struktury społecznej.

W artykule wykorzystane zostaną kategorie teoretyczne odnoszące się do procesów zamknięcia społecznego (social closure) i powiązanych z nimi pojęć wykluczenia i monopolizacji. Dostarczają one bowiem użytecznego aparatu pojęciowego dla analiz selekcyjnej funkcji szkolnictwa w zamkniętym rasowo systemie apartheidu. Warto w tym miejscu nawiązać do bardziej ogólnego poglądu A. Sawisz, która stwierdza, że „rozważanie problematyki zamknięcia w socjologii (...) może być samo w sobie interesujące i pożyteczne również w analizie problemów socjologii szczegółowych" (1987: 142).

Procesy segregacji rasowej powiązane są z tworzeniem się wyraźnego zróżnicowania pomiędzy poszczególnymi kategoriami, tworzącymi strukturę społeczną. Procesy stratyfikacji funkcjonujące w społeczeństwach segregowanych rasowo posiadają swoją specyficzną dynamikę. Uwarunkowana jest ona w znaczący sposób instytucjonalnymi działaniami, podejmowanymi przez państwo, służącymi uprawomocnianiu i sankcjonowaniu istniejącego porządku społecznego. Działania takie obejmują przede wszystkim zastosowanie różnorodnych strategii wykluczania reprezentantów podporządkowanych kategorii rasowych z dostępu do przywilejów służących członkom kategorii dominującej. Kryterium wykluczenia stanowią w tym kontekście statusy przypisane (sama przynależność do danej rasy, a więc przede wszystkim cechy fizyczne, np. kolor skóry). Równocześnie mechanizmy wykluczenia w społeczeństwach segregowanych rasowo - powiązane z tak przyjmowanym 
kryterium segregacji - posiadają znaczący wpływ na statusy osiągane jednostki (takie jak choćby uzyskane wykształcenie, pozycja zawodowa czy dochody). Oznacza to, iż mechanizmy wykluczenia w procesach segregacji odgrywały podstawową rolę $\mathrm{w}$ determinowaniu możliwości, jakie uzyskać mogły jednostki z poszczególnych kategorii w społeczeństwie ustratyfikowanym rasowo.

Z perspektywy analiz selekcyjnej roli szkolnictwa w tworzeniu i odtwarzaniu systemu apartheidu w Afryce Południowej koncepcja zamknięcia społecznego M. Webera dostarcza stosownych kategorii analitycznych służących zrozumieniu mechanizmów działania odmiennych grup i kategorii społecznych w tym kraju, a przede wszystkim procesów segregacji rasowej. M. Weber zwraca bowiem uwagę, że - obok takich czynników, jak pochodzenie społeczne, miejsce zamieszkania, język czy religia - rasa stanowi jedną z kluczowych kategorii służących identyfikacji grupy, kategoryzacji w układzie hierarchicznym oraz w konsekwencji - wykluczaniu. Według M. Webera, utrzymywanie monopolistycznych praktyk zmierza do ustanowienia porządku prawnego, który ogranicza konkurencję za pośrednictwem powstałych sformalizowanych monopoli (Weber 1968: 342). Monopol jednej grupy jest zatem kluczem do zrozumienia relacji społecznych opartych na silnie zróżnicowanym dostępie do różnych dóbr w społeczeństwie, zarówno w procesach monopolizacji, jak i w procesach ekspansji (także terytorialnej) grupy dominującej (tamże: 344-348).

Do weberowskiej kategorii zamknięcia nawiązał Frank Parkin. Teoretyk ten zwrócił uwagę na potencjał tkwiący w zarysowanej przez M. Webera koncepcji zamknięcia społecznego. Podjął on równocześnie próbę rozszerzenia kategorii zamknięcia i monopolizacji (Sawisz 1987: 143). Według tego teoretyka, „strategie wykluczenia stanowią dominujący aspekt zamknięcia społecznego we wszystkich systemach stratyfikacji" (Parkin 1979: 45). Spoglądając z perspektywy historycznej, wzrost i konsolidacja grup panujących zostawała osiągana za pośrednictwem monopolistycznej kontroli nad zasobami, takimi jak ziemia, ezoteryczna wiedza czy broń, w ograniczonym kręgu ludzi uznawanych za odpowiednich (tamże: 46). Istotą wykluczenia jest wzmacnianie własnej dominacji i uzyskiwanie uprzywilejowanej pozycji za pośrednictwem procesów podporządkowywania - tworzenie nowej grupy lub warstwy (Parkin 1974: 4). Jednym z przykładów, jaki podaje w tym kontekście F. Parkin, jest właśnie usankcjonowana prawnie sytuacja wykluczenia Czarnych przez reprezentantów białej kategorii rasowej w systemie apartheidu (Parkin 1979: 59).

Kategoria zamknięcia społecznego, którą wykorzystać można do analiz selekcyjnej funkcji systemu szkolnictwa w okresie apartheidu, obecna jest również w teorii monopolizacji i wykluczenia Raymonda Murphy'ego (Murphy 1988: 1-9). Teoretyk ten zwrócił uwagę zarówno na złożoność mechanizmów zamknięcia, które przybierają różne formy w państwach o odmiennych ustrojach politycznych, jak i na fakt ich funkcjonowania na różnych poziomach struktury społecznej. Teoria R. Murphy'ego - wyprowadzana z kategorii zamknięcia społecznego Maxa Webera 
- akcentuje niejednorodność źródeł zamknięcia społecznego, a równocześnie możliwość współwystępowania różnych typów zamknięcia. Niezwykle ciekawe $\mathrm{z}$ perspektywy analiz funkcjonowania szkolnictwa $\mathrm{w}$ systemie apartheidu jest odniesienie się przez R. Murphy'ego do sytuacji segregacji rasowej w Afryce Południowej. Teoretyk ten bowiem stwierdza, iż w analizach sytuacji apartheidu należy odnosić się do dwu głównych form wykluczenia, funkcjonujących na różnych poziomach struktury społecznej w tym kraju - i usankcjonowanych przez obowiązujące prawo. Pierwsze z nich odnosiło się do kategoryzacji rasowej, natomiast drugie do kwestii własności i zasobów. Tak opisuje konsekwencje działania podwójnej struktury zamknięcia w systemie apartheidu R. Murphy:

struktura wykluczenia w Afryce Południowej tworzyła dodatkową linię klasowego rozłamu istniejącego poniżej klas posiadających - oddzielającą Czarnych od reprezentantów białej klasy robotniczej. Jej rezultatem było istnienie czarnej podklasy. Zarówno robotnicy czarnoskórzy, jak i reprezentanci białej klasy robotniczej stanowili podporządkowane kategorie w Afryce południowej: pierwsi przez oddziaływanie dwu głównych kryteriów wykluczenia (apartheidu i własności), a drudzy przez oddziaływanie jednego kryterium (własności), przy czym podwójne podporządkowanie posiadało bardziej dotkliwe konsekwencje (Murphy 1988: 74).

Przywoływani teoretycy (F. Parkin, R. Murphy) - nawiązujący do koncepcji M. Webera - podkreślają rolę formalnych zaświadczeń - kredencjałów (credentials) w sferze praktyk monopolizacji. Warto w tym miejscu odnieść się do jeszcze jednej z teorii podejmującej analizę kategorii zamknięcia społecznego i monopolizacji, która odnosi się stricte do współczesnych systemów edukacyjnych. Koncepcja kredencjalizmu, której autorem jest R. Collins, zwraca bowiem uwagę na rolę edukacji (i powiązanego z nią systemu formalnych zaświadczeń - dyplomów (credentials)) w mechanizmach zamknięcia społecznego (Collins 1979: 196-197).

Charakteryzując społeczeństwa funkcjonujące w oparciu o zasady kredencjalizmu, R. Collins zwraca uwagę na odmienne ich typy, funkcjonujące w różnych ustrojach państwowych i systemach politycznych (Melosik 2001: 150). Z perspektywy analiz polityki segregacji rasowej w Afryce Południowej i roli, jaką w tym systemie odgrywał system edukacji, szczególnie użyteczną wydaje się - wprowadzona przez R. Collinsa - kategoria faszystowskiego kredencjalizmu (credential fascism) (Collins 1979: 196).

Odnosi się ona do utworzonego przez reprezentantów grup dominujących systemu zamknięcia $w$ ramach szkolnictwa wyższego ograniczającego reprezentantom odmiennych kategorii społecznych (przede wszystkim rasowych i etnicznych) dostęp do studiów lub wręcz wykluczających ich z uczestnictwa. Kryteria rasowe i etniczne stanowią $\mathrm{w}$ tego typu systemach podstawowy czynnik wykluczenia społecznego. Tło dla działań dyskryminacyjnych stanowi najczęściej ideologia, 
sformułowana w oparciu o poglądy dotyczące nadrzędności białej rasy nad innymi kategoriami rasowymi, czy tezy o genetycznie zdeterminowanych uzdolnieniach (w których reprezentanci niebiałych kategorii rasowych czy grup etnicznych posiadają je znacząco niższe). Działania podejmowane w systemach opartych na takich formach zamknięcia społecznego mogą prowadzić zarówno do tworzenia odrębnych instytucji dla reprezentantów poszczególnych kategorii i grup rasowych oraz etnicznych, jak i wyłączenia całych populacji z możliwości uzyskiwania wykształcenia akademickiego. Faszystowski kredencjalizm stanowi w tym kontekście - jak pisze R. Collins - „wsparcie arbitralnego systemu dominacji służącego wyłączności jednej grupy" (tamże: 196).

W analizach dotyczących selekcyjnej funkcji edukacji w systemie segregacji rasowej w Afryce Południowej, jak i roli szkolnictwa w sankcjonowaniu i utrzymywaniu apartheidu, zasadne jest przywołanie koncepcji teoretycznych, które charakteryzują mechanizmy separacji i dominacji. Wydaje się, iż zasygnalizowane powyżej koncepcje i powiązane $\mathrm{z}$ nimi kategorie teoretyczne doskonale wpisują się $\mathrm{w}$ istotę zagadnień podejmowanych $\mathrm{w}$ artykule, dostarczając aparatu pojęciowego adekwatnego do analizy tytułowych zależności.

\section{Selekcyjna funkcja edukacji w systemie apartheidu}

Ewolucja systemu segregacji rasowej na terytorium Afryki Południowej następowała stopniowo, wraz z rozwojem państwowości, procesami industrializacji oraz instytucjonalizacji rzeczywistości społeczno-ekonomicznej. Jednak dopiero wprowadzenie apartheidu jako systemu politycznego w 1948 r. usankcjonowało istnienie całej struktury zależności, w której kategoria rasy stała się wyznacznikiem funkcjonowania jednostek i grup społecznych we wszystkich sferach instytucjonalnych i pozainstytucjonalnych (Van den Berghe 1967: 96).

Współcześnie słowo apartheid jest powszechnie znanym pojęciem i jednym z niewielu tak znanych terminów politycznych odnoszących się do segregacji na świecie (Giliomee, Schlemmer 1989: 40). I choć używa się go często do określenia różnorodnych sytuacji segregacji rasowej w odmiennych kontekstach politycznych - jak na przykład sytuacji segregacji rasowej w Stanach Zjednoczonych (Tejani 2017: 451), sytuacji politycznej pomiędzy grupami etnicznymi w Izraelu (Farsakh 2015: 161) czy innych krajach afrykańskich (Austin 1975: 43) - to jednak pojęcie apartheidu odnosi się przede wszystkim do systemu społeczno-ekonomicznego i politycznego w Afryce Południowej (funkcjonującego w latach 1948-1994).

J. Balicki, pisząc o istocie zmian, jakie zaszły w systemie segregacji rasowej w Afryce Południowej po 1948 r., zwraca uwagę przede wszystkim na wzmocnienie separacji rasowej w systemie apartheidu: 
Polityka dyskryminowania wszystkich niebiałych grup ludności na korzyść ludności białej leżała u podstaw rządów w Afryce Południowej od bardzo dawna. Między segregacją rasową uprawianą przez wszystkie poprzednie rządy południowoafrykańskie a polityką apartheidu realizowaną od 1948 roku nie ma różnic jakościowych. Można natomiast mówić o zmianach ilościowych. Wyrażały się one w tym, że rasistowskich aktów ustawodawczych było więcej, że były obszerniejsze i bardziej szczegółowe, sięgały do wszystkich dziedzin życia, wypełniały istniejące dotychczas luki w barierach wznoszonych między rasami (Balicki 1980: 42).

Według tego autora można zatem mówić przede wszystkim o rozszerzeniu oddziaływania polityki segregacji rasowej na inne dziedziny życia, a także o ilościowym wzroście w zakresie intensywności oddziaływań polityki segregacyjnej, co przekładało się na kolejne akty prawne uprawomocniające system odrębnego rozwoju, a także rosnącą kontrolę państwa w tym zakresie. Potwierdzają to również słowa D. Welsha, który zauważa, iż

w 1948 roku, momencie rozpoczęcia apartheidu, Afryka Południowa była już w pełni podzielonym rasowo, segregowanym państwem. Apartheid mógł się usadowić i rozwijać w już uprzednio powstałych instytucjach i wykorzystywać je bardziej bezwzględnie. Segregacja w okresie przed 1948 rokiem służyła interesom głównych sektorów białego społeczeństwa, w szczególności rolnictwu, przemysłowi wydobywczemu i rynkowi pracy (...). W okresie przejścia przed i po 1948 roku, apartheid został sprzężony z ideologią nacjonalizmu oraz religijnego partykularyzmu i to uczyniło różnicę sprzyjającą wzmocnieniu procesów jego wprowadzania (Welsch 2009: 47).

Z drugiej strony, zwraca się uwagę na dwie istotne różnice pomiędzy wcześniejszą polityką segregacji rasowej a politycznym ustrojem apartheidu, wprowadzonym przez Partię Narodową w 1948 r. Po pierwsze, wcześniejsza polityka segregacji kładła nacisk na horyzontalny podział pomiędzy poszczególnymi kategoriami rasowymi. Z kolei apartheid w założeniach uwydatniał konieczność wertykalnego podziału pomiędzy grupami etnicznymi czy narodami o równym statusie. Po drugie, apartheid znacznie odróżniał się pod względem opisu roli jednostki w społeczeństwie. Odbiegał on przy tym znacząco od liberalnego modelu, w którym jednostka posiada prawa niezależnie od zasad funkcjonowania społeczeństwa (Śliwerski 2001: 87-88). W konserwatywnym modelu ideologicznym polityki apartheidu jednostka mogła zrealizować swoje cele wyłącznie w ramach społeczeństwa. W systemie apartheidu - jak zauważają w tym kontekście H. Gilomee i L. Schlemmer -

jednostka była postrzegana jako nieposiadająca żadnych praw poza tymi, które naród (volk) otrzymał do istnienia przez Boga; wszystkie prawa jednostki są zatem wyprowadzane ze wspólnoty (...). W tym sensie, apartheid może być po- 
strzegany bardziej jako odrębny rozwój niż poszerzanie segregacji (Giliomee, Schlemmer 1989: 40-41).

Niezależnie od interpretacji, w rzeczywistości praktyka społeczno-polityczna systemu apartheidu zmierzała konsekwentnie do dalszego potwierdzania nadrzędności białej rasy nad pozostałymi trzema kategoriami rasowymi (Azjatów, Koloredów oraz Afrykanów). Rozwój tego systemu zmierzał w kierunku znaczącego ograniczania praw reprezentantów niebiałych kategorii rasowych. Temu służyła kontynuacja działań mających na celu wprowadzanie segregacji rasowej w różne sfery funkcjonowania południowoafrykańskiego społeczeństwa. Jak stwierdza przy tym P. L. van den Berghe, „żadne inne państwo w historii świata nie włożyło tyle swojej energii i zasobów w narzucenie segregacji rasowej co Afryka Południowa, począwszy od 1948 roku" (Van den Berghe 1966: 408-409).

Funkcjonowanie szkolnictwa w państwie apartheidu pozostawało w ścisłym związku z jego systemem ekonomicznym, społecznym i politycznym. Tym samym zróżnicowanie rasowe we wszystkich nieomal sferach życia posiadało zwrotny wpływ na sposoby działania systemu edukacji na poszczególnych poziomach. Równocześnie rasistowska ideologia obowiązująca w Południowej Afryce uprawomocniała ogromne nierówności istniejące w sferze szkolnictwa tworzonego dla reprezentantów poszczególnych kategorii rasowych. Temu służyło również tworzenie aktów prawnych regulujących zasady i warunki funkcjonowania systemów szkolnictwa przeznaczonych dla poszczególnych kategorii rasowych. Jak zauważają w odniesieniu do prawnych uwarunkowań szkolnictwa dla Czarnych H. Wolpe i E. Unterhalter,

celem Ustawy o edukacji Bantu nie było stworzenie rasowej stratyfikacji zawodowej czy ideologicznego podporządkowania, ponieważ funkcjonowały one już wcześniej, wspierane przez porządek polityczny i ekonomiczny. To co zakładano, odnosiło się do reprodukcji kapitalistycznych relacji ekonomicznych - opartych na nierównych relacjach rasowych, wykorzystywaniu czarnej siły roboczej oraz utrwalaniu podziałów klasowych (Wolpe, Unterhalter 1991: 4).

Selekcyjny system funkcjonujący w Afryce Południowej przed 1994 r. był

w wysokim stopniu zorientowany na egzaminowanie, z coroczną promocją na koniec roku, a także dwoma ocenami śródrocznymi ze wszystkich przedmiotów. Przejście do następnej klasy powiązane było z uzyskaniem pozytywnych ocen na egzaminach końcowych. Egzaminy te miały zatem przemożny wpływ na rodziców, nauczycieli i uczniów, stanowiąc zarazem część ukrytego programu (Herman 1995: 265).

Selekcyjny charakter południowoafrykańskiego systemu edukacji posiadał równocześnie silne powiązania z polityką apartheidu, całkowicie determinując możliwości jednostek w zakresie dostępu do szkolnictwa wyższego. 
Struktura szkolnictwa dla Czarnych wyznaczona w Ustawie o edukacji Bantu (Bantu Education Act) zakładała funkcjonowanie szkoły podstawowej składającej się z ośmiu klas. Kształcenie w szkole podstawowej podzielone zostało na dwa etapy. Pierwszy z nich - szkoły podstawowej pierwszego stopnia (lower-primary school) - obejmował cztery lata kształcenia. Kolejnym etapem była również czteroletnia tak zwana szkoła podstawowa drugiego stopnia (higher-primary school). Przez pierwsze cztery lata pierwszego etapu obowiązywała automatyczna promocja uczniów do następnej klasy. Po klasie czwartej dzieci zdawały test, który stanowił próg selekcyjny do następnego etapu edukacji. Wiele afrykańskich dzieci (nie zdając testu) na tym etapie kończyło swoje kształcenie (Christie, Collins 1982: 70).

Aż do 1974 r. struktura szkolnictwa dla Czarnych była odmienna od tej, w której podejmowali kształcenie reprezentanci innych kategorii rasowych. Obejmowała ona czteroletni etap szkoły podstawowej pierwszego stopnia, czteroletni etap szkoły podstawowej drugiego stopnia, trzyletni etap szkoły średniej pierwszego stopnia oraz dwuletni etap szkoły średniej drugiego stopnia. W konsekwencji, szkoła podstawowa i średnia dla Czarnych funkcjonowała według schematu $4+4+3+2$. Od 1975 r. struktura ta uległa upodobnieniu do modelu kształcenia obowiązującego w całym szkolnictwie (Behr 1988: 106) (por. schemat 1). Równocześnie trzeba podkreślić, iż obowiązek szkolny w systemie apartheidu nie obejmował reprezentantów rasy czarnej (Johnson 1982: 220).

Schemat 1. Czterofazowa struktura szkolnictwa podstawowego i średniego w RPA wraz z podziałem na klasy [standards] i fazy kształcenia oraz odpowiadający im wiek uczniów

\begin{tabular}{l|c|c|c|c|c|c|c|c|c|c|c|c|} 
Rok kształcenia & 1 & 2 & 3 & 4 & 5 & 6 & 7 & 8 & 9 & 10 & 11 & 12 \\
\hline Klasa [standard] & Sub & $\begin{array}{c}\text { Sub } \\
\text { A }\end{array}$ & $\begin{array}{c}\text { Std } \\
1\end{array}$ & $\begin{array}{c}\text { Std } \\
2\end{array}$ & $\begin{array}{c}\text { Std } \\
3\end{array}$ & $\begin{array}{c}\text { Std } \\
4\end{array}$ & $\begin{array}{c}\text { Std } \\
5\end{array}$ & $\begin{array}{c}\text { Std } \\
6\end{array}$ & $\begin{array}{c}\text { Std } \\
7\end{array}$ & $\begin{array}{c}\text { Std } \\
8\end{array}$ & $\begin{array}{c}\text { Std } \\
9\end{array}$ & $\begin{array}{c}\text { Std } \\
10\end{array}$ \\
\hline Faza kształcenia & \multicolumn{2}{|c|}{$\begin{array}{c}\text { Szkoła podstawowa } \\
\text { [Junior Primary] }\end{array}$} & \multicolumn{2}{|c|}{$\begin{array}{c}\text { Szkoła podstawowa } \\
\text { [Senior primary] }\end{array}$} & \multicolumn{2}{|c|}{$\begin{array}{c}\text { Szkoła średnia } \\
\text { [Junior Secondary] }\end{array}$} & \multicolumn{3}{|c|}{$\begin{array}{c}\text { Szkoła średnia } \\
\text { [Senior Secondary] }\end{array}$} \\
\hline Wiek & 6 & 7 & 8 & 9 & 10 & 11 & 12 & 13 & 14 & 15 & 16 & 17 \\
18
\end{tabular}

Uwaga: system edukacji podstawowej i średniej obejmował 12 lat kształcenia, przy czym kształcenie początkowe trwało trzy lata i obejmowało trzy klasy (Substandard A, Substandard B oraz Standard 1).

Źródło: A. L. Behr, Education in South Africa. Origins, Issues and Trends: 1652-1988, Cape Town: Academica, Pretoria 1988, s. 106.

Jeszcze inny schemat $\mathrm{w}$ ramach powyższej struktury szkolnictwa obowiązywał (aż do 1972 r.) w kształceniu dzieci i młodzieży zaklasyfikowanych do kategorii Koloredów. W tym czasie obejmował on dwuletni etap szkoły podstawowej pierwszego stopnia (Substandard A i Substandard B), pięcioletni etap szkoły podstawo- 
wej drugiego stopnia (Standard 1-5), trzyletni etap szkoły średniej pierwszego stopnia (Standard 6-8) oraz dwuletni etap szkoły średniej drugiego stopnia (Standard 9-10). Począwszy od 1972 r., reprezentanci kategorii Koloredów rozpoczęli kształcenie w czterofazowym systemie edukacji, skonstruowanym według schematu $3+3+3+3$.

Od 1975 r. dla wszystkich grup rasowych wprowadzono 12-letni tryb kształcenia w szkolnictwie podstawowym oraz średnim. Struktura kształcenia w szkolnictwie dla Białych obejmowała 12 lat kształcenia (w ramach czterofazowego systemu edukacji podstawowej i średniej), przy czym klasa siódma (Standard 5) włączona była w ramy szkoły podstawowej (Behr 1988: 106). Podobny schemat struktury szkolnictwa obowiązywał w edukacji dla Azjatów.

Zróżnicowanie rasowe stanowiło kluczowy kontekst służący rozmieszczaniu jednostek w hierarchicznej strukturze społecznej. Od początku funkcjonowania systemu apartheidu istniały ogromne dysproporcje w każdym z aspektów funkcjonowania poszczególnych podsystemów w ramach południowoafrykańskiego systemu edukacji, służących reprezentantom odmiennych kategorii rasowych (Macquarrie 1960: 173).

Tabela 1. Wybrane wskaźniki funkcjonowania szkolnictwa w 1955 r. (podział według kategorii rasowych)

\begin{tabular}{|l|c|c|c|}
\hline \multicolumn{1}{|c|}{ Wskaźnik } & Biali & Azjaci i Koloredzi & Afrykanie \\
\hline $\begin{array}{l}\text { Liczba nauczycieli w szkołach } \\
\text { publicznych }\end{array}$ & 23747 & 10233 & 22218 \\
\hline $\begin{array}{l}\text { Liczba uczniów przypadająca na } \\
\text { nauczyciela }\end{array}$ & 24,2 & 32,6 & 45,3 \\
\hline $\begin{array}{l}\text { Roczne wydatki rządowe } \\
\text { (w funtach) }\end{array}$ & 28789000 & 7889000 & 8016000 \\
\hline $\begin{array}{l}\text { Wydatki w przeliczeniu na ucznia } \\
\text { (w funtach) }\end{array}$ & 50,0 & 23,7 & 8,0 \\
\hline $\begin{array}{l}\text { Szacowana liczba dzieci w wieku } \\
\text { 5-15 lat w populacji }\end{array}$ & 614040 & 481046 & 2455148 \\
\hline $\begin{array}{l}\text { Liczba dzieci w wieku 5-15 lat } \\
\text { objętych kształceniem }\end{array}$ & 570489 & 324564 & 921045 \\
\hline $\begin{array}{l}\text { Odsetek dzieci w wieku 5-15 lat } \\
\text { objętych kształceniem }\end{array}$ & $93 \%$ & $68 \%$ & $38 \%$ \\
\hline
\end{tabular}

Źródło: J. W. Macquarrie, Race and Education in South Africa, "The Phi Delta Kappan" 1960, vol. 41, no 4, s. 173.

Już od momentu rozpoczęcia przez dziecko kształcenia, zróżnicowane rasowo systemy szkolnictwa generowały gigantyczne nierówności w sferze możliwości kontynuacji edukacji na kolejnych szczeblach kształcenia, wykluczając reprezentan- 
tów niebiałych kategorii rasowych z możliwości pełnego uczestnictwa w systemie edukacji. Od wprowadzenia w 1953 r. Ustawy o edukacji Bantu (Bantu Education Act) system edukacji w Afryce Południowej cechował się szczególnie ogromną nierównością, jeśli chodzi o szkolnictwo dla Afrykanów w stosunku do dominującej białej mniejszości. Nierówności edukacyjne dotyczyły również innych niebiałych kategorii rasowych. Przede wszystkim trzeba zwrócić uwagę na ogromną liczbę dzieci i młodych ludzi pozostających poza oddziaływaniem formalnego systemu edukacji. Dane zebrane przy okazji kolejnych spisów powszechnych pokazują wyraźne dysproporcje $\mathrm{w}$ tym zakresie, pokrywające się $\mathrm{z}$ istnieniem podziałów rasowych w społeczeństwie (Horrell, Horner, Hudson 1975: 340).

Tabela 2. Liczba jednostek nieposiadających wykształcenia w 1960 i 1970 r. (dane dla reprezentantów poszczególnych kategorii rasowych)

\begin{tabular}{|c|c|c|c|}
\hline \multirow[t]{2}{*}{$\begin{array}{c}\text { Kategoria } \\
\text { rasowa }\end{array}$} & $\begin{array}{c}\text { Liczba jednostek } \\
\text { powyżej } 15 \text { lat }\end{array}$ & $\begin{array}{c}\text { Liczba jednostek } \\
\text { powyżej } 15 \text { lat } \\
\text { nieposiadających } \\
\text { wykształcenia }\end{array}$ & $\begin{array}{l}\text { Odsetek jednostek } \\
\text { powyżej } 15 \text { lat } \\
\text { nieposiadających } \\
\text { wykształcenia }\end{array}$ \\
\hline & \multicolumn{3}{|c|}{$1960 \mathrm{r}}$. \\
\hline Biali & 2082000 & 40400 & 1,9 \\
\hline Koloredzi & 827000 & 276300 & 38,0 \\
\hline Azjaci & 264000 & 75900 & 28,7 \\
\hline Afrykanie & 6393000 & 3993100 & 62,5 \\
\hline \multirow[t]{2}{*}{ Łącznie: } & 9566000 & 4385700 & 45,9 \\
\hline & \multicolumn{3}{|c|}{$1970 \mathrm{r}}$. \\
\hline Biali & 2576000 & 23300 & 0,9 \\
\hline Koloredzi & 1102000 & 259700 & 23,6 \\
\hline Azjaci & 369000 & 61600 & 16,7 \\
\hline Afrykanie & 8629000 & 4469700 & 51,8 \\
\hline Łącznie: & 12676000 & 4814300 & 38,0 \\
\hline
\end{tabular}

Źródło: M. Horrell, D. Horner, J. Hudson, A Survey of Race Relations in South Africa, South African Institute of Race Relations, Johannesburg 1975, s. 340.

Także biorąc pod uwagę sam początek procesu kształcenia, a więc szkolnictwo podstawowe, należy wskazać istniejący ogromny problem w zakresie odsiewu szkolnego. W połowie lat siedemdziesiątych ponad 34\% czarnoskórych dzieci i około 28\% dzieci ze społeczności Koloredów bądź to odpadło, bądź powtarzało pierwszą klasę szkoły podstawowej (Substandard A - SSA). Trzeba przy tym zaznaczyć, iż w 1991 r. kształciło się 5891172 czarnoskórych uczniów w szkolnic- 
twie podstawowym prowadzonym przez Ministerstwo Edukacji i Kształcenia Zawodowego oraz samorządne prowincje, a równocześnie około 1,6 miliona dzieci w wieku od 6 do 13 lat nie uczęszczało do szkół (Motala 1995: 164).

Także kolejne dekady nie przyniosły znaczącej poprawy. Szacunkowe dane wskazują, iż w 1991 r. odsiewem szkolnym na poziomie klasy pierwszej dotkniętych zostało 16\% czarnoskórych dzieci podejmujących wcześniej naukę w tej klasie. Kolejne istotne momenty selekcji, w których odsiewem dotkniętych zostało łącznie 26\% dzieci, miały miejsce w klasie ósmej (Standard 6), a także w klasie 12 (Standard 10).

Oznacza to, iż znacząca część afrykańskich dzieci, które podjęły kształcenie w klasie pierwszej (Substandard A), nie kontynuowało jej już w klasie drugiej (Substandard B). Spoglądając na perspektywę pełnego cyklu edukacji (dwunastu lat kształcenia w szkole podstawowej i średniej - aż do momentu zdawania przez uczniów egzaminu maturalnego), można stwierdzić, iż w 1990 r. spośród wszystkich czarnoskórych dzieci, które rozpoczęły naukę w klasie pierwszej, zaledwie 29\% miało szanse na dotarcie do dwunastej klasy (Standard 10). Równocześnie spośród tych niespełna 30\%, zaledwie 36\% udawało się zdać egzamin maturalny (tamże: 165).

Dysproporcje w tej sferze dostrzegalne były niezwykle wyraźnie, spoglądając przez pryzmat zróżnicowania rasowego. Szczególnie nieuprzywilejowaną kategorią rasową była (poza czarną) także populacja Koloredów. Spośród dzieci - reprezentantów populacji Koloredów, które rozpoczęły swoją edukację w pierwszej klasie szkoły podstawowej w 1963 r., 12-letni proces edukacji udało się ukończyć zaledwie niewielkiemu odsetkowi $(4,4 \%)$ z nich. Dwanaście lat kształcenia ukończyło jeszcze mniej dzieci czarnych (por. tabela 3).

Tabela 3. Odsetek uczniów, którzy rozpoczęli edukację w pierwszej klasie szkoły podstawowej w 1963 r. i ukończyli 12 lat kształcenia (podział według kategorii rasowych)

\begin{tabular}{|c|c|c|c|c|}
\hline $\begin{array}{c}\text { Kategoria } \\
\text { rasowa }\end{array}$ & Azjaci & Biali & Czarni & Koloredzi \\
\hline Odsetek & 22,30 & 58,40 & 1,96 & 4,40 \\
\hline
\end{tabular}

Źródło: A. L. Behr, Education in South Africa. Origins, Issues and Trends: 1652-1988, Cape Town: Academica, Pretoria 1988, s. 41.

Istotny kontekst selekcji szkolnych w Afryce Południowej okresu apartheidu dotyczył również zróżnicowania przestrzennego. Z tej perspektywy trzeba także zwrócić uwagę na istotne różnice odnośnie do tego zjawiska pomiędzy arbitralnie wyznaczonymi przez białe władze rezerwatami dla Afrykanów, tak zwanymi terytoriami samorządnymi (czy inaczej bantustanami). Generalnie można stwierdzić, iż w samych nierównościach ekonomicznych zawarta już była predyspozycja 
dla reprezentantów określonych kategorii rasowych. Edukacja w bantustanach powiązana była z uzyskiwaniem przez dzieci kształcenia niższej jakości, co przekładało się na wyniki, jakie uzyskiwały one w kolejnych klasach szkoły podstawowej (Taylor 1989: 55-58).

W praktyce zatem, aby jeszcze raz powtórzyć - zróżnicowane systemy szkolnictwa, funkcjonujące według logiki dyskryminacji, powodowały ogromne nierówności w możliwościach, jakie posiadały jednostki pochodzące z odmiennych kategorii rasowych. Dostrzegalne były one już od początku kariery edukacyjnej dziecka. Wystarczy spojrzeć na wyniki szkolne, jakie uzyskiwały dzieci z różnych kategorii rasowych (Behr 1988: 119) (por. tabela 4).

Tabela 4. Postępy dzieci z odmiennych kategorii rasowych (rozumiane jako promocja do następnej klasy odsetka dzieci z danego rocznika), począwszy od klasy pierwszej (Substandard A) do klasy czwartej (Standard 2), w okresie od 1974 do 1977 r.

\begin{tabular}{|c|c|c|c|c|c|c|c|c|c|c|c|c|c|c|c|c|}
\hline & \multicolumn{4}{|c|}{ Azjaci } & \multicolumn{4}{|c|}{ Czarni } & \multicolumn{4}{|c|}{ Koloredzi } & \multicolumn{4}{|c|}{ Biali } \\
\hline & $\mathrm{kl} .1^{*}$ & $\mathrm{kl} .2^{* *}$ & \begin{tabular}{|l|l}
$*$ & $\mathrm{kl} .3$
\end{tabular} & $\mathrm{kl} .4$ & $\mathrm{kl} .1$ & $\mathrm{kl} .2$ & $\mathrm{kl} .3$ & $\mathrm{kl} .4$ & $\mathrm{kl} .1$ & $\mathrm{kl} .2$ & $\mathrm{kl} .3$ & $\mathrm{kl} .4$ & kl.1 & $\mathrm{kl} .2$ & $\mathrm{kl} .3$ & $\mathrm{kl} .4$ \\
\hline 1974 & 100 & & & & 100 & & & & 100 & & & & 100 & & & \\
\hline 1975 & & 100 & & & & 65,3 & & & & 78,81 & & & & 96,33 & & \\
\hline 1976 & & & 90,95 & & & & 51,0 & & & & 60,25 & & & & 94,89 & \\
\hline 1977 & & & & 88,16 & & & & 42,0 & & & & 52,26 & & & & 92,38 \\
\hline
\end{tabular}

* Pierwsza klasa szkoły podstawowej (Substandard A);

** Druga klasa szkoły podstawowej (Substandard B).

Źródło: A. L. Behr, Education in South Africa. Origins, Issues and Trends: 1652-1988, Cape Town: Academica, Pretoria 1988, s. 119.

Spoglądając na uwarunkowania wysokiego odsiewu szkolnego czarnoskórych dzieci, można stwierdzić różnorodne przyczyny tego zjawiska. Jedną z przyczyn tego stanu rzeczy był niski kapitał społeczno-kulturowy i ekonomiczny rodzin dzieci pochodzących ze środowisk defaworyzowanych. Wysoki poziom bezrobocia wśród czarnoskórych rodzin zamieszkujących w bantustanach powodował zjawiska ubóstwa posiadające zwrotny wpływ na inne sfery życia. W wielu czarnoskórych rodzinach oboje bądź przynajmniej jedno z rodziców nie posiadało wykształcenia, pozostając analfabetami. W rodzinach tych formalne wykształcenie nie było wartościowane wysoko. W konsekwencji dzieci nie były wcale posyłane do szkół bądź - nie posiadając żadnego wsparcia ze strony rodziców - szybko stawały się odsiewem szkolnym w selekcyjnym systemie południowoafrykańskiego szkolnictwa. Brak obowiązku szkolnego dla Afrykanów także determinował poziom wykształcenia całej populacji mieszczącej się w ramach tej kategorii rasowej (tamże: 57). 
Warto wspomnieć w tym miejscu o specyfice kształcenia w obszarach wiejskich, a w szczególności tej formie edukacji, jaką stanowiły szkoły na farmach. Szkoły takie powstawały systematycznie wiele dekad przed okresem zalegalizowanego apartheidu. W 1949 r. funkcjonowało 937 misyjnych, 10 łączonych, 85 ministerialnych oraz 87 plemiennych szkół na farmach. Prowadzone były one przez organizacje misyjne, niezależnych białych farmerów, a także Afrykanów. W tym czasie uczęszczało do nich 100934 uczniów (Horrell 1963: 57).

Pomimo ciągłej zmiany osób oraz instytucji prowadzących tego typu działalność oświatową, liczba szkół na farmach systematycznie rosła podobnie jak populacja uczniów z niej korzystających. W 1960 r. do szkół takich uczęszczało 172761 uczniów, a w 1967 r. było ich już 239 600. Oznacza to wzrost populacji uczniów w szkołach na farmach o około 39\%. Pomimo tak znacznego wzrostu kształcącej się populacji, jak można stwierdzić, zaledwie jedna czwarta dzieci w wieku szkolnym zamieszkujących obszary wiejskie była objęta kształceniem. Większość afrykańskich dzieci pracujących na farmach nie otrzymywała jednak żadnej edukacji, a samo kształcenie oferowane w wiejskich szkołach było niskiej jakości - służąc wyłącznie przygotowaniu do funkcjonowania w roli taniej siły roboczej. Większość szkół na farmach oferowało kształcenie w zakresie trzech klas edukacji elementarnej, a tylko nieliczne $\mathrm{z}$ nich edukację łączoną (zawierającą program kolejnych trzech klas szkoły podstawowej). Spośród 1698 szkół na farmach działających w 1960 r. większość zatrudniała jednego nauczyciela. W tym czasie około 89\% uczniów kończyło swoją edukację na trzeciej klasie, a zaledwie 11\% kontynuowało ją w dalszych klasach szkoły podstawowej (Horrell 1964: 66-67). Uczniowie chcący kontynuować swoją edukację zmuszeni byli do migracji do szkół średnich w miastach, a od 1963 r. do szkół średnich funkcjonujących w obszarach rezerwatów (bantustanów). W rzeczywistości jednak liczba uczniów podejmujących dalsze kształcenie była marginalna ze względu na brak możliwości opłacenia przez rodziców czesnego w średnich szkołach z internatami (Horrell 1968: 154).

W konsekwencji dostępność edukacji w obszarach wiejskich Południowej Afryki zależna była zarówno od woli białego farmera utrzymywania i prowadzenia szkoły, jak i możliwości rodziców uczniów w sferze opłacenia kosztów ich kształcenia. Równocześnie dla czarnych uczniów nie funkcjonowały żadne formy transportu szkolnego czy systemu hosteli, pomimo istnienia takich form dla uczniów białych zamieszkujących obszary daleko położone. Konieczność pokonywania długiego dystansu do szkoły powodowała zmęczenie uczniów i częste opuszczanie przez nich lekcji (szczególnie w okresie zimowym). Nieobecność uczniów związana była również z obawą przed gwałtem czy porwaniem w drodze do szkoły (Christie, Gordon 1992: 411-412; Christie, Gaganakis 1989: 77-85).

Inny czynnik, różnicujący poziom wykształcenia (oraz inne wskaźniki) w ramach kategorii Czarnych, powiązany był z przynależnością do poszczególnych, różniących się znacząco pomiędzy sobą tubylczych grup etnicznych. Istotne dla postrzegania edukacji z perspektywy odmiennych kategorii rasowych były również 
obce treści kształcenia, zawarte w podręcznikach szkolnych (Harber 1989: 186). Kolejną przyczynę posiadającą wpływ na zjawiska odsiewu szkolnego był język używany w szkołach (Mesthrie 2004: 22). Stosunek do tych kwestii odzwierciedlany był także w narastającym buncie przeciw narzucanemu systemowi segregacji rasowej i ogromnym nierównościom społeczno-ekonomicznym, których doświadczali reprezentanci ras niebiałych - a w szczególności rasy czarnej. Niechęć i przemoc ze strony uczniów wobec czarnych inspektorów oświatowych wizytujących szkoły w obszarach bantustanów (i postrzeganych jako reprezentantów systemu opresji) tylko potwierdza wspomniane uwarunkowania (Christie, Gordon 1992: 412). Nasilające się w latach osiemdziesiątych i kontynuowane do lat dziewięćdziesiątych protesty czarnoskórych społeczności często obejmowały instytucje edukacyjne. Kultura sprzeciwu wobec apartheidu, wyrażana w sferze edukacji między innymi hasłem „żadnego kształcenia aż do wyzwolenia” (no education before liberation), posiadała swój istotny wpływ na wyniki szkolne osiągane przez czarnoskórych uczniów (Herman 1995: 268).

Trzeba zwrócić uwagę również na uwarunkowania tkwiące w samym systemie szkolnictwa, a mianowicie niedostateczny sposób finansowania szkół, ich nieadekwatne wyposażenie (w sale lekcyjne, materiały dydaktyczne, pomoce naukowe, podręczniki) czy też ogromne braki w sferze wykwalifikowanej kadry (Taylor 1989: 6-7).

Pomimo reform politycznych podejmowanych w systemie szkolnictwa nie udało się w istotny sposób zredukować zjawiska odsiewu szkolnego wśród czarnoskórych uczniów. Pod koniec funkcjonowania systemu apartheidu (a więc na początku lat dziewięćdziesiątych) zjawisko to było doskonale widoczne w szkolnictwie RPA. Dane dla 1990 r. wskazują na dramatyczny odsetek czarnych dzieci niekończących kolejnych etapów szkolnictwa obowiązkowego. Dotyczy to również kształcenia na poziomie średnim drugiego stopnia (por. tabela 5).

Jak już wspomniano, ważnym czynnikiem, posiadającym wpływ na osiągnięcia szkolne uczniów z odmiennych kategorii rasowych był poziom wykształcenia nauczycieli. W 1986 r. minister edukacji odpowiedzialny za kwestie szkolnictwa dla Czarnych stwierdził, że 90\% nauczycieli nauczających w szkołach dla Afrykanów nie miało podstawowych kwalifikacji do pracy z dziećmi (a więc nie posiadało nawet świadectwa trzyletniego kursu przygotowującego dla nauczycieli (PostSenior Certificate)). Zdecydowanie lepsza sytuacja miała miejsce w szkołach przeznaczonych dla populacji Azjatów i Koloredów (Behr 1988: 117-118).

Ogromne nierówności strukturalne funkcjonujące w odmiennych - segregowanych rasowo - systemach szkolnictwa odnosiły się również do tego wskaźnika, jakim jest proporcja nauczycieli w stosunku do uczniów. Przepełnione klasy w czarnych szkołach, w powiązaniu z nieodpowiednim ich wyposażeniem w pomoce dydaktyczne uniemożliwiały często właściwe, efektywne i skuteczne nauczanie. Dla przykładu, w roku 1990 proporcja nauczycieli w stosunku do uczniów w szkołach podstawowych dla Białych była 1 do 20, natomiast 1 do 49 w szkołach 


\begin{tabular}{|c|c|c|c|c|}
\hline \multicolumn{5}{|c|}{ 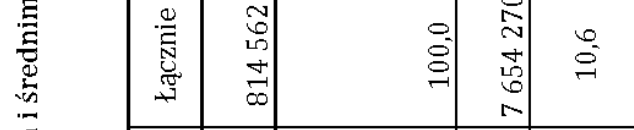 } \\
\hline$\infty \frac{9}{\square}$ & $\begin{array}{l}3 \\
8 \\
8 \\
\infty \\
\sigma\end{array}$ & $\begin{array}{ll}0 \\
-1 \\
-1\end{array}$ & \begin{tabular}{l}
\multirow{N}{N}{} \\
$\stackrel{\mathrm{N}}{\mathrm{N}}$
\end{tabular} & $\overrightarrow{\bar{m}}$ \\
\hline 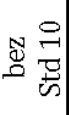 & $\begin{array}{l}8 \\
\Xi \\
\sigma \\
\sigma\end{array}$ & 8 & 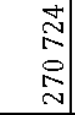 & $\overrightarrow{\overbrace{}^{\circ}}$ \\
\hline 吾 & 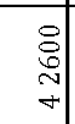 & בy & $\frac{\sigma}{\sigma}$ & $\stackrel{m}{m}$ \\
\hline $\begin{array}{l}\infty \\
\text { 劳 }\end{array}$ & $\begin{array}{l}\stackrel{8}{\Xi} \\
\stackrel{9}{+}\end{array}$ & $m$ & 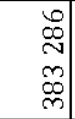 & $\underset{\exists}{\exists}$ \\
\hline 焉 & $\begin{array}{l}8 \\
8 \\
5\end{array}$ & $\begin{array}{l}\sigma \\
0.5\end{array}$ & 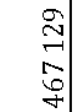 & $\stackrel{m}{\varrho}$ \\
\hline 营 & $\begin{array}{l}8 \\
8 \\
8\end{array}$ & $=$ & $\begin{array}{l}\infty \\
0 \\
10 \\
8 \\
0 \\
0\end{array}$ & $\exists$ \\
\hline 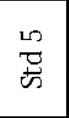 & $\begin{array}{l}8 \\
\stackrel{8}{15} \\
\text { ले }\end{array}$ & $\stackrel{\sim}{=}$ & 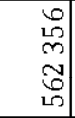 & ${ }_{6}^{-1}$ \\
\hline$\vec{D}$ & $\begin{array}{l}8 \\
8 \\
6 \\
0\end{array}$ & $\begin{array}{ll}0 \\
0 \\
10\end{array}$ & 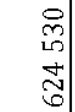 & $\stackrel{\forall}{*}$ \\
\hline$m$ & $\begin{array}{l}8 \\
5 \\
6 \\
6\end{array}$ & g. & $\begin{array}{l}\stackrel{9}{8} \\
\stackrel{5}{0} \\
\stackrel{0}{0}\end{array}$ & $\stackrel{\infty}{N}$ \\
\hline 蛋 & $\begin{array}{l}\stackrel{8}{\Xi} \\
\stackrel{m}{m}\end{array}$ & $\Rightarrow$ & 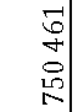 & $\stackrel{\rightleftarrows}{*}$ \\
\hline$\vec{D}$ & $\begin{array}{l}8 \\
\Xi \\
\sigma \\
+\end{array}$ & 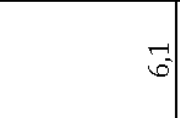 & 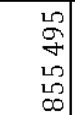 & $\begin{array}{l}\infty \\
15^{\circ}\end{array}$ \\
\hline 羔 & 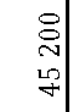 & $\begin{array}{l}10 \\
10\end{array}$ & 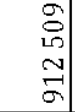 & $\stackrel{8}{8}$ \\
\hline 荧 & $\begin{array}{l}\Xi \\
\Xi \\
8\end{array}$ & t⿹-口 & $\begin{array}{l}0 \\
\Xi \\
0 \\
0 \\
-1\end{array}$ & $\frac{9}{-1}$ \\
\hline & 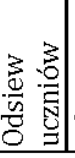 & 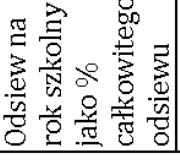 & $\frac{3}{0}$ & 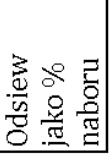 \\
\hline
\end{tabular}

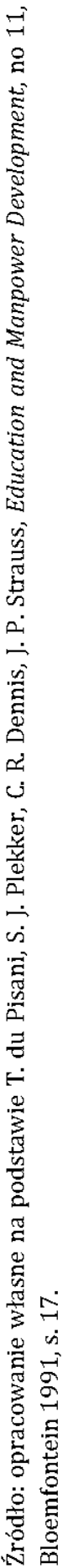


dla Czarnych. Dla uczniów ze społeczności Koloredów proporcja ta w szkolnictwie podstawowym wynosiła 1 do 25, natomiast dla uczniów ze społeczności Azjatów - 1 do 24 (Du Pisani, Plekker, Dennis, Strauss 1991: 18). Oznacza to, że w szkołach dla Afrykanów średnia liczba uczniów w klasach szkoły podstawowej często przekraczała 50 uczniów. Możliwości kształcenia w tak licznych klasach znacząco utrudniały proces dydaktyczny, stanowiąc jedną z głównych przyczyn niskich wyników, jakie uzyskiwali uczniowie należący do tej kategorii rasowej.

Ryc. 1. Liczba uczniów przypadających na jednego nauczyciela w szkolnictwie podstawowym i średnim RPA, dane dla 1990 r., podział według kategorii rasowych

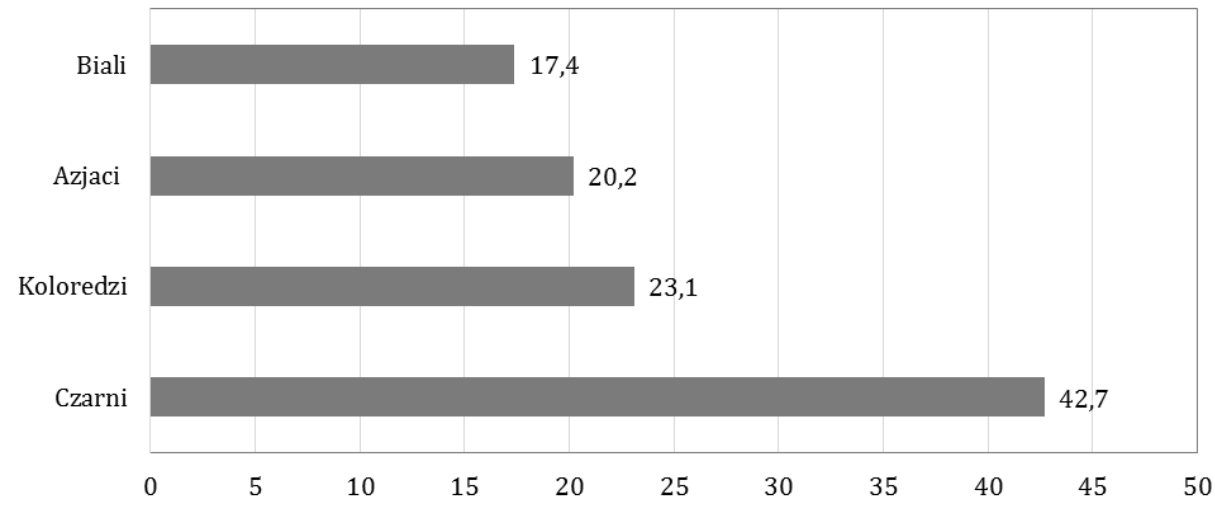

Źródło: opracowanie własne na podstawie T. du Pisani, S. J. Plekker, C. R. Dennis, J. P. Strauss, Education and Manpower Development, no 11, Bloemfontein 1991, s. 18.

Kluczowym czynnikiem determinującym sposoby funkcjonowania uczniów i nauczycieli w segregowanym rasowo systemie szkolnictwa było także jego finansowanie. Ogromne nierówności w sposobach finansowania szkolnictwa - przebiegające wzdłuż obowiązujących w RPA kategorii rasowych - wyznaczały możliwości i ograniczenia, jakie napotykali reprezentanci poszczególnych kategorii rasowych w swojej karierze edukacyjnej.

Kwestie nierówności w sferze finansowania szkolnictwa były widoczne, spoglądając choćby z perspektywy proporcji wydatków przeznaczanych na ucznia. W tym kontekście dostrzegalne są ewidentne nierówności, jakie obecne były $\mathrm{w}$ sferze finansowania kształcenia obywateli w RPA, ze względu na ich przynależność do odmiennych kategorii rasowych. I tak, wydatki na edukację białego ucznia w poszczególnych latach były nawet dziesięciokrotnie większe niż kwoty przeznaczane na kształcenie dziecka afrykańskiego. Dysproporcje w sferze wydatków na uczniów pochodzących z pozostałych kategorii rasowych były również bardzo duże (Unterhalter 1991: 52). 
Ryc. 2. Zmiany w sferze finansowania edukacji w systemie apartheidu w latach 1953-1989, w przeliczeniu na ucznia, w tysiącach randów, podział według kategorii rasowych

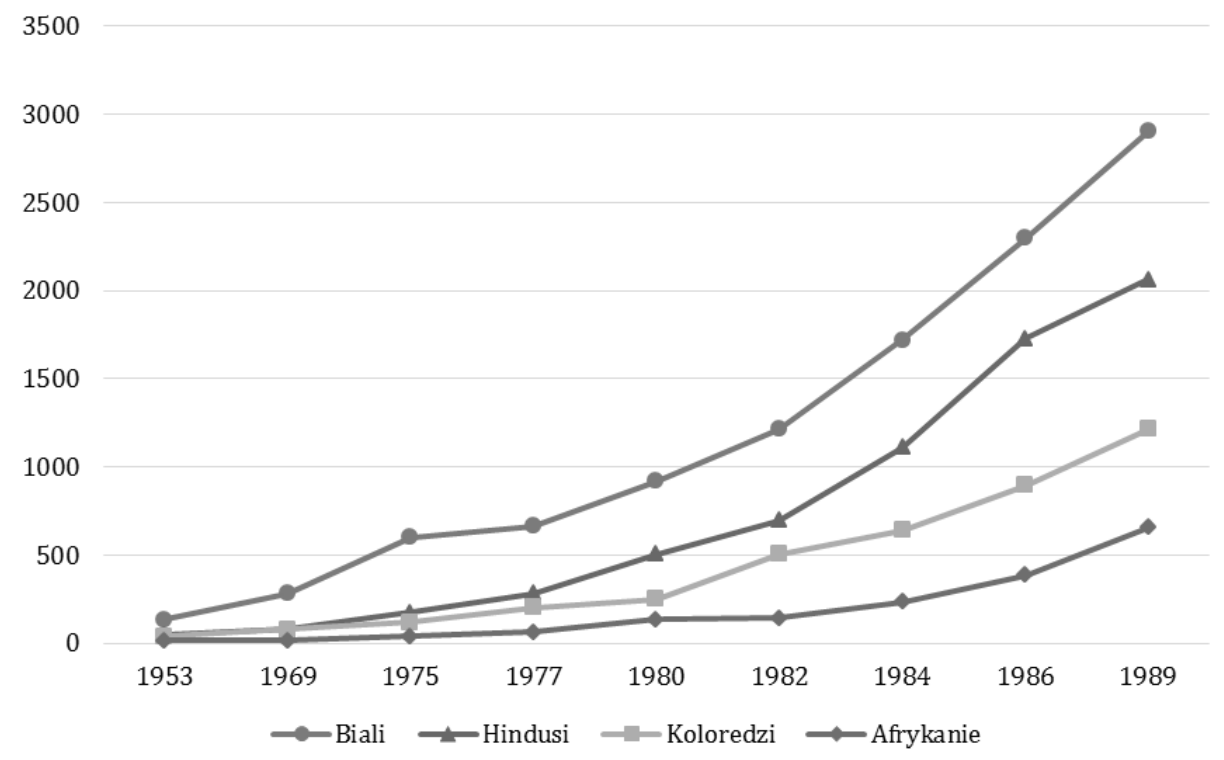

Źródło: K. Tihanyi, Blending in the Rainbow Nation. The Racial Integration of Schoolsand. Its Implication for Reconciliation in Post-Apartheid South Africa, Lexington Books, Lanham 2006, s. 47.

W efekcie, pomimo zmian wprowadzanych w systemie finansowania kształcenia dla poszczególnych ras przez kolejne dekady, pod koniec funkcjonowania systemu apartheidu funkcjonowały ogromne dysproporcje w sferze osiągnięć uczniów w systemie szkolnictwa podzielonym według kategorii rasowych. W konsekwencji liczba dzieci pochodzących z nieuprzywilejowanych kategorii rasowych różniła się znacząco na kolejnych poziomach kształcenia.

Najbardziej istotny dla procesów selekcji szkolnej był - jak można stwierdzić dostęp do szkolnictwa wyższego. W rasowo ustratyfikowanym południowoafrykańskim społeczeństwie istniały bowiem mechanizmy zamknięcia społecznego, uniemożliwiające dostęp do instytucji edukacji wyższej reprezentantom nieuprzywilejowanych kategorii rasowych. Warto w tym miejscu zwrócić uwagę na niezwykle selekcyjny egzamin kończący szkołę średnią drugiego stopnia. Stanowił on bowiem kryterium służące selekcji na poziom szkolnictwa wyższego. Egzamin ten służył w południowoafrykańskim systemie szkolnictwa do wyłaniania jednostek predestynowanych do podjęcia studiów uniwersyteckich. Trzeba przy tym stwierdzić, iż stanowił on „sito” służące selekcji najbardziej uzdolnionych jednostek, które miały w przyszłości zajmować najbardziej wyeksponowane pozycje społeczne (Herman 1995: 265). 
Selekcja na poziom szkolnictwa wyższego w RPA oparta była na wynikach egzaminów kończących dwunastoletni cykl kształcenia (obejmujący szkołę podstawową oraz szkołę średnią). Ukończenie dwunastej klasy (Standard 10) szkoły średniej powiązane było z uzyskaniem świadectwa (School-leaving Certificate). Świadectwo to mogło zawierać oceny z egzaminów kończących ten etap edukacji (Senior Certificate), a ponadto $\mathrm{z}$ dodatkowego egzaminu maturalnego (Matriculation Exemption) - w przypadku gdy uczeń podejmował wysiłek jego zdawania. Egzaminy Senior Certificate obejmowały sześć bądź siedem przedmiotów, spośród których uczeń musiał zdać pięć na ocenę dobrą lub bardzo dobrą. W ramach tego z pierwszego języka kształcenia uczeń musiał uzyskać ocenę bardzo dobrą. Z kolei zdawanie egzaminu maturalnego Matriculation Exemption powiązane było z koniecznością uzyskania ocen bardzo dobrych (poza językiem) z dwóch kolejnych egzaminów.

Możliwości kształcenia na południowoafrykańskich uczelniach wyższych powiązane były $\mathrm{z}$ przejściem przez selekcyjną procedurę egzaminów kończących szkołę średnią. Jak zauważa przy tym H. D. Herman,

kryteria selekcji na uniwersytety, politechniki oraz kolegia oparte były przede wszystkim na ocenach z egzaminu maturalnego. Na poziomie, w którym niższe wymogi stanowiły kryterium selekcji, jak w przypadku kolegiów technicznych czy szkół handlowych, to oceny na świadectwie były używane jako główny wyznacznik (Herman 1995: 265).

Organizacja egzaminów dla uczniów należących do poszczególnych kategorii rasowych w Afryce Południowej leżała w gestii odrębnych ministerstw oraz instytucji. Równocześnie kryteria egzaminacyjne były podobne (wyznaczane przez Radę Egzaminów Maturalnych (Joint Matriculation Board)). Egzaminy w czterech niezależnych republikach (Bophutatswanie, Ciskei, Transkei i Venda) oraz pozostałych republikach samorządnych przeprowadzane były przez Ministerstwo Edukacji i Kształcenia Zawodowego (Department od Education and Training) odpowiedzialne za edukację Afrykanów. Począwszy od 1986 r. powołano ponadto Południowoafrykańską Radę ds. Świadectw (South African Certification Council). Jej zadaniem było koordynowanie świadectw i dyplomów wydawanych przez różne ministerstwa i departamenty odpowiedzialne za kształcenie w podzielonym rasowo i administracyjnie kraju, a także dbałość o jednolite standardy w zakresie wymogów egzaminacyjnych (Du Pisani, Plekker, Dennis, Strauss 1991: 14).

Zdawalność egzaminów końcowych kończących szkołę średnią była dla reprezentantów odmiennych kategorii rasowych wynikiem - opisywanych wcześniej nierówności tkwiących zarówno w systemie edukacji, jak i będących pochodną uwarunkowań społecznych, ekonomicznych i politycznych. Twierdzenie takie odnieść można zarówno do kwestii statystycznych, powiązanych z liczbą reprezentantów poszczególnych kategorii rasowych, którym udało się ukończyć pełny 
(dwunastoletni) cykl kształcenia, jak i wynikami uzyskiwanymi przez nich w dwunastej klasie szkoły średniej. Z tej perspektywy widać bowiem wyraźnie konsekwencje działalności szkolnictwa opartego między innymi na - opisywanych wcześniej - dysproporcjach.

Tabela 6. Wyniki egzaminacyjne uczniów szkoły średniej w 12 klasie (Standard 10), w latach 1986-1990, podział według kategorii rasowych

\begin{tabular}{|l|l|c|c|c|c|c|}
\hline \multirow{2}{*}{ Rok } & \multicolumn{1}{|c|}{ Kategoria } & Czarni & Biali & Koloredzi & Azjaci & 七ącznie \\
\hline \multirow{2}{*}{1986} & Liczba uczniów w 12 klasie & 100012 & 64327 & 17624 & 11406 & 193369 \\
& Uzyskujący School leaving Certificate & 38150 & 34447 & 9212 & 6142 & 87951 \\
& Zdający pomyślnie Matric. Exemption & 13460 & 28071 & 2707 & 3787 & 48025 \\
& Pełna liczba zdających pomyślnie & 51610 & 59915 & 11919 & 9929 & 133373 \\
& Odsetek zdających pomyślnie & 51,6 & 93,1 & 67,6 & 87,1 & 69,0 \\
\hline \multirow{2}{*}{1987} & Liczba uczniów w 12 klasie & 150119 & 64627 & 18289 & 12429 & 245509 \\
& Uzyskujący School leaving Certificate & 59601 & 34024 & 9825 & 7211 & 110661 \\
& Zdający pomyślnie Matric. Exemption & 24597 & 27508 & 3465 & 4625 & 60195 \\
& Pełna liczba zdających pomyślnie & 84198 & 61532 & 13290 & 11836 & 170856 \\
& Odsetek zdających pomyślnie & 56,1 & 95,1 & 72,7 & 95,2 & 69,6 \\
\hline \multirow{2}{*}{1988} & Liczba uczniów w 12 klasie & 187123 & 69549 & 21456 & 13221 & 291349 \\
& Uzyskujący School leaving Certificate & 75500 & 37683 & 10679 & 7180 & 131042 \\
& Zdający pomyślnie Matric. Exemption & 30685 & 29126 & 3492 & 5397 & 68700 \\
& Pełna liczba zdających pomyślnie & 106185 & 66809 & 14171 & 12577 & 199742 \\
& Odsetek zdających pomyślnie & 56,7 & 96,1 & 66,0 & 95,1 & 68,6 \\
\hline \multirow{2}{*}{1989} & Liczba uczniów w 12 klasie & 209319 & 70666 & 22666 & 14191 & 316842 \\
& Uzyskujący School leaving Certificate & 66153 & 37892 & 12431 & 7393 & 123869 \\
& Zdający pomyślnie Matric. Exemption & 21357 & 29933 & 4044 & 5889 & 61223 \\
& Pełna liczba zdających pomyślnie & 87510 & 67825 & 16475 & 13282 & 185092 \\
& Odsetek zdających pomyślnie & 41,8 & 96,0 & 72,7 & 93,6 & 58,4 \\
\hline \multirow{2}{*}{1990} & Liczba uczniów w 12 klasie & 255498 & 68097 & 22315 & 14542 & 360452 \\
& Uzyskujący School leaving Certificate & 72837 & 37262 & 13234 & 7201 & 130541 \\
& Zdający pomyślnie Matric. Exemption & 21025 & 27986 & 4487 & 6614 & 60112 \\
& Pełna liczba zdających pomyślnie & 93862 & 65255 & 17721 & 13815 & 190653 \\
& Odsetek zdających pomyślnie & 36,7 & 95,8 & 79,4 & 95,0 & 52,9 \\
\hline
\end{tabular}

Źródło: opracowanie własne na podstawie T. du Pisani, S. J. Plekker, C. R. Dennis, J. P. Strauss, Education and Manpower Development, no 11, Bloemfontein 1991, s. 14.

Już sama liczba podchodzących do egzaminu Senior Certificate kończącego szkołę średnią - biorąc pod uwagę proporcje reprezentantów poszczególnych kategorii rasowych w populacji RPA - ukazuje gigantyczne nierówności. Podobne stwierdzenia można odnieść do liczby uczniów zdających ten egzamin pozytywnie. 
Ryc. 3. Odsetek absolwentów ostatniej (dwunastej) klasy (Standard 10) szkoły średniej drugiego stopnia, którzy zdali egzaminy końcowe, dane dla lat 1986-1990, według kategorii rasowych

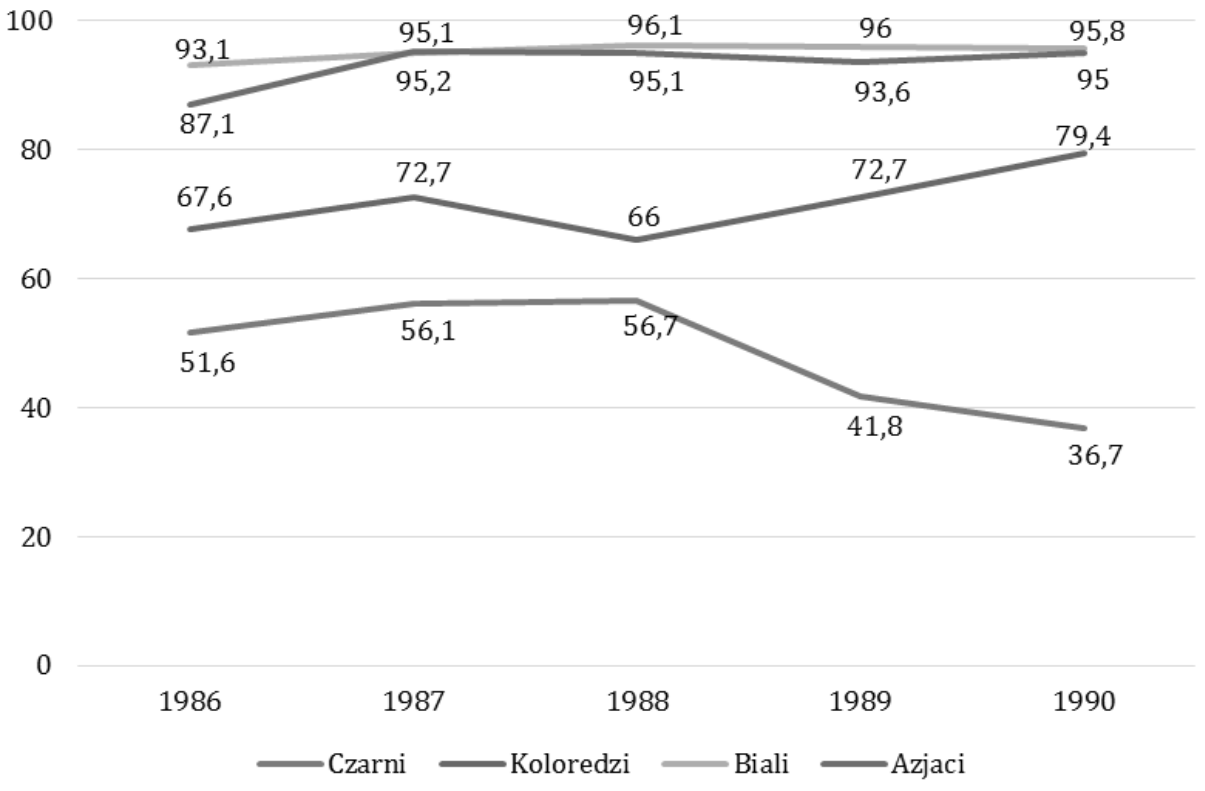

Źródło: opracowanie własne na podstawie T. du Pisani, S. J. Plekker, C. R. Dennis, J. P. Strauss, Education and Manpower Development, no 11, Bloemfontein 1991, s. 14.

Dane zawarte na rycinie 3. jednoznacznie wskazują na ogromne dysproporcje w zakresie możliwości kontynuacji dalszej drogi edukacyjnej, jakie w ważnym momencie selekcyjnym uzyskiwali reprezentanci odmiennych kategorii rasowych. Jeszcze bardziej widoczne są one w odniesieniu do tego wskaźnika, jakim jest uzyskanie wysokich ocen na egzaminie maturalnym (matriculation exemption). Można bowiem stwierdzić, że spośród niewielkiej liczby absolwentów szkół średnich drugiego stopnia tylko pewnej ich części udawało się zdać pozytywnie matriculation exemption. Także i w tym przypadku dostrzegalne są wyraźne dysproporcje - biegnące wzdłuż kategorii rasowych (por. rycina 4).

Konsekwencje tego podziału doskonale widoczne były na poziomie szkolnictwa wyższego. Cała struktura szkolnictwa wyższego w Republice Południowej Afryki również była podzielona według kryterium rasowego i ściśle przystosowana do potrzeb państwa funkcjonującego według zasad apartheidu (Bunting 2006: 4951). Implikacje polityki segregacji w szkolnictwie wyższym powiązane były zarówno $\mathrm{z}$ mechanizmami dyskryminacji obecnymi w sposobach funkcjonowania poszczególnych kategorii rasowych; dostrzegalne były one także we wskaźnikach 
ilościowych charakteryzujących działanie edukacji na tym poziomie. Dotyczyło to choćby liczby uczelni wyższych przeznaczonych dla reprezentantów poszczególnych ras, jak i liczby studentów kształcących się w uniwersytetach.

Ryc. 4. Odsetek absolwentów ostatniej (dwunastej) klasy (Standard 10) szkoły średniej drugiego stopnia, którzy zdali egzamin matriculation exemption, dane dla lat 1986-1990, podział według kategorii rasowych

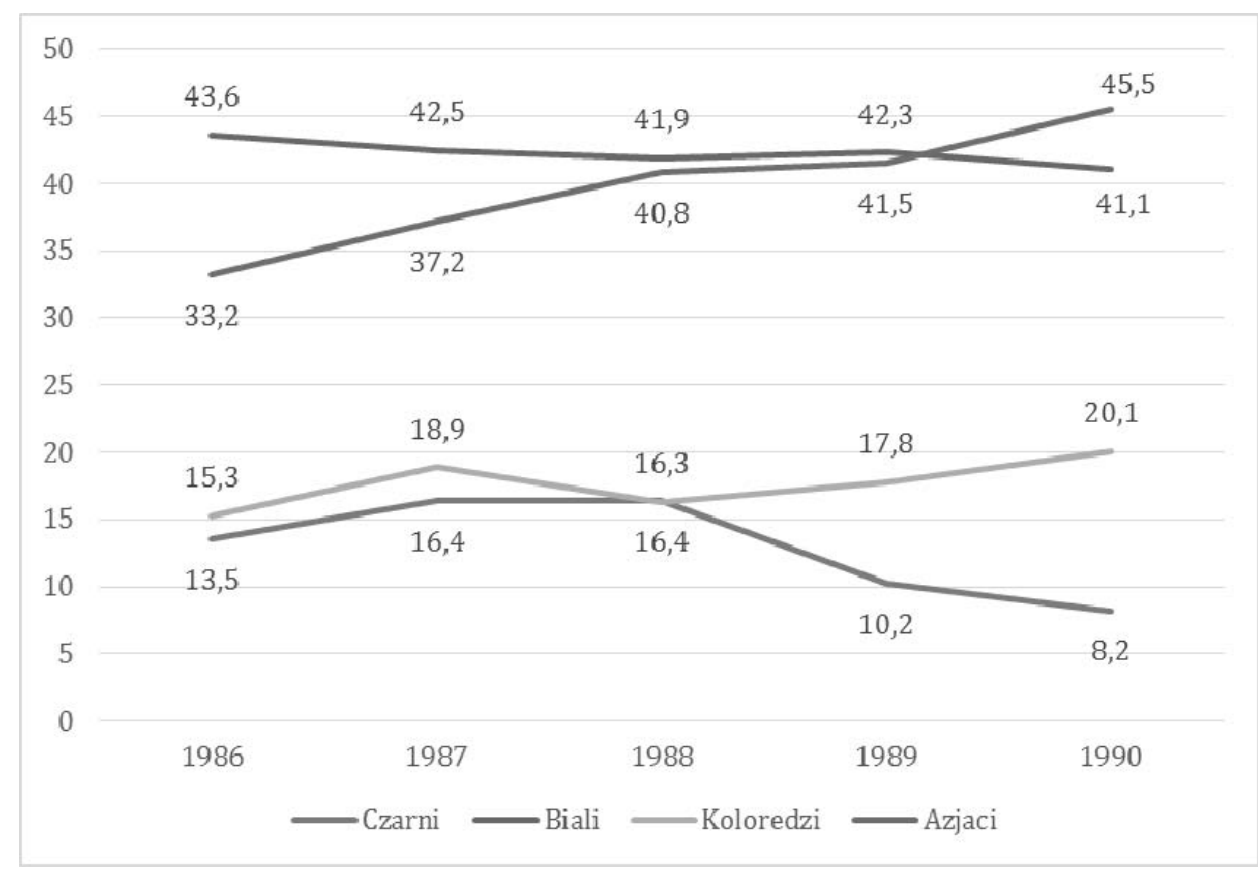

Źródło: opracowanie własne na podstawie T. du Pisani, S. J. Plekker, C. R. Dennis, J. P. Strauss, Education and Manpower Development, no 11, Bloemfontein 1991, s. 14.

Analiza danych przedstawionych w tabeli 7 nasuwa kilka wniosków odnośnie do funkcjonowania systemu szkolnictwa wyższego w Południowej Afryce w połowie lat siedemdziesiątych. Po pierwsze, można stwierdzić, iż w tym okresie system szkolnictwa wyższego miał charakter wysoce elitarny. Oznacza to, iż uniwersytety w RPA przyjmowały corocznie relatywnie niewielką liczbę studentów (w odniesieniu do liczebności populacji kraju). Po drugie, można dostrzec ogromne nierówności w sferze naboru na uniwersytety jednostek z poszczególnych kategorii rasowych. Dane te pokazują praktyki monopolizacji sektora szkolnictwa wyższego przez Białych, co przekłada się na uzyskiwanie przez nich wyłączności w sferze uzyskiwania kredencjałów akademickich warunkujących zajmowanie najwyższych pozycji społecznych. W tym kontekście, jak można to stwierdzić, szkolnictwo 
wyższe uczestniczyło w praktykach zamknięcia społecznego, a system faszystowskiego kredencjalizmu funkcjonujący w sferze edukacji akademickiej w Republice Południowej Afryki wykluczał całe kategorie ludzi z możliwości awansu społecznego.

Tabela 7. Liczba studentów z odmiennych kategorii rasowych, przyjętych na uniwersytety w RPA, dane dla $1974 \mathrm{r}$.

\begin{tabular}{|l|c|c|c|c|c|c|}
\hline \multicolumn{1}{|c|}{ Uniwersytet } & Biali & Koloredzi & Hindusi & Chińczycy & Afrykanie & Łącznie \\
\hline Cape Town & 8449 & 404 & 82 & 31 & 6 & 8972 \\
Durban-Westville & - & - & 2342 & - & - & 2342 \\
Fort Hare & - & - & - & - & 1029 & 1029 \\
Natal & 7198 & 91 & 347 & 8 & 256 & 7900 \\
Orange Free State & 6685 & - & - & - & - & 6685 \\
Port Elizabeth & 1967 & - & - & - & - & 1967 \\
Potchefstroom & 6415 & 2 & - & - & 4 & 6421 \\
Pretoria & 14313 & - & - & - & - & 14313 \\
Rand Africaans & 2143 & - & - & - & - & 2143 \\
Rhodes & 2299 & - & 3 & 39 & 1 & 2342 \\
Stellenbosch & 9284 & - & - & - & - & 9284 \\
South Africa & 26981 & 1177 & 1946 & 60 & 3995 & 34159 \\
The North & - & - & - & - & 1509 & 1509 \\
The Western Cape & - & 1440 & - & - & - & 1440 \\
The Witwatersrand & 9855 & 28 & 143 & 231 & 42 & 10299 \\
Zululand & - & - & - & - & 1003 & 1003 \\
\hline tącznie & 95589 & 3142 & 4863 & 369 & 7845 & 111808 \\
\hline
\end{tabular}

Źródło: M. Horrell, D. Horner, J. Hudson, A Survey of Race Relations in South Africa, South African Institute of Race Relations, Johannesburg 1975, s. 369.

Równocześnie dane te ukazują niewielką liczbę reprezentantów innych kategorii rasowych, podejmujących kształcenie w uniwersytetach RPA. Ich kształcenie ograniczone zostało przede wszystkim do uczelni etnicznych, które utworzone zostały w celu segregacji rasowej. Studenci z kategorii Azjatów, Koloredów czy Afrykanów - kształcących się w sferze szkolnictwa wyższego w Afryce Południowej - stanowili niewielkie grupy reprezentujące poszczególne społeczności. Byli oni przygotowywani do zajmowania wyższych pozycji społecznych, zwykle w ramach hierarchicznego układu społecznego, funkcjonującego wzdłuż podziałów rasowych.

Trzeba równocześnie zauważyć, iż w związku z polityką apartheidu nastąpiło nieomal pełne oddzielenie studentów pochodzących z odrębnych kategorii rasowych. W rzeczywistości lat siedemdziesiątych działały bowiem tylko nieliczne uczelnie, w których kształcili się reprezentanci o różnym kolorze skóry. Jednak i w tych uniwersytetach dostrzegalna była wyraźna dysproporcja w sferze naboru studentów z odmiennych kategorii rasowych. Reprezentanci rasy białej byli 
w każdym przypadku nadreprezentowani (zarówno w liczbach bezwzględnych, jak i w odniesieniu do procentowego udziału w zestawieniu $\mathrm{z}$ ich liczebnością $\mathrm{w}$ populacji). Spoglądając z tej perspektywy, szczególnie niedoreprezentowani w edukacji uniwersyteckiej byli studenci czarnoskórzy.

Dopiero od 1983 r. zaistniała możliwość podejmowania studiów przez czarnoskórych studentów w tradycyjnie zarezerwowanych dla białych uczelniach RPA. Poprawka do ustawy o uniwersytetach z 1983 r. (Universities Amendment Act of 1983) powstała zarówno w wyniku wewnętrznych protestów w RPA, jak i nacisków międzynarodowej opinii publicznej (Mabokela 2000: 29).

\section{Zakończenie}

Podsumowując, trzeba stwierdzić, iż system edukacji w południowoafrykańskim społeczeństwie (a w rzeczywistości odrębne jego podsystemy przeznaczone dla poszczególnych kategorii rasowych) generowały ogromne dysproporcje i nierówności, monopolizując dostęp do najlepszych pozycji społecznych dla reprezentantów rasy białej. Odnosiło się to do diametralnie odmiennych możliwości uzyskania sukcesu życiowego, jakie uzyskiwali uczniowie należący do poszczególnych kategorii rasowych. Nierówności te dotyczyły zarówno dostępu do edukacji, zróżnicowania poziomu kształcenia na poszczególnych jej szczeblach, jak i wielu innych uwarunkowań strukturalnych, materialnych oraz mentalnych. Selekcyjna funkcja edukacji wykorzystywana była w ramach polityki apartheidu do bezpośredniego i celowego wykluczania reprezentantów poszczególnych niebiałych kategorii rasowych, a w szczególności reprezentantów rasy czarnej. Konsekwencją tak zaprogramowanej polityki edukacyjnej stało się utrzymywanie dystansu wszystkich niebiałych populacji wobec dominującej (białej) kategorii rasowej.

Dopiero demokratyczne przemiany w latach dziewięćdziesiątych (związane z odrzuceniem polityki apartheidu), a także rozwój demokratycznego państwa w pierwszych dekadach XX w. przełamały instytucjonalny proces rasowych podziałów. Nie znaczy to jednak, iż piętno wielu wieków dyskryminacji zostało zmyte. Konsekwencje apartheidu w sferze szkolnictwa widoczne są bowiem również współcześnie (Atmore 2013: 153-155; Wangenge-Ouma 2012: 833; Spaull 2013: 436-438; Cele 2009: 39; Higgins i in. 2016: 286).

\section{Bibliografia}

Atmore E. (2013) Early childhood development in South Africa - progress since the end of apartheid, "International Journal of Early Years Education", 21 (2-3).

Austin R. (1975) Racism and apartheid in southern Africa: Rhodesia, Paris, The Unesco Press. 
Balicki J. (1980) Afrykanerzy, Afrykanie, Apartheid, Warszawa, Wydawnictwo „Iskry”.

Behr A. L. (1988) Education in South Africa. Origins, Issues and Trends: 1652-1988, Pretoria, Cape Town: Academica.

Bunting I. A. (2006) The Higher Education Landscape Under Apartheid w: Transformation in Higher Education. Global Pressures and Local Realities, N. Cloete, P. Maassen, R. Fehnel, T. Moja, T. Gibbon, H. Perold (eds.), Dordrecht, The Editors. Nico Cloete.

Cele M. (2009) South Africa. Post-Apartheid Higher Education: The Role and Challenges Facing Student Activists w: Youth and Higher Education in Africa: The Cases of Cameroon, South Africa, Eritrea and Zimbabwe, D. P. Chimankikire (ed.), Dakar, http://www.codesria.org/spip.php?article418\&lang=en

Christie P., Collins C. (1982) Bantu Education: apartheid ideology or labour reproduction?, "Comparative Education", 18 (1): 59-75.

Christie P., Gaganakis M. (1989) Farm Schools in South Africa: The Face of Rural Apartheid, "Comparative Education Review", 33 (1): 77-92.

Christie P., Gordon A. (1992) Politics, Poverty and Education in Rural South Africa, "British Journal of Sociology of Education", 13 (4): 399-418.

Collins R. (1979) The Credential Society. An Historical Sociology of Education and Stratification, New York, Publisher: Academic Press.

Davenport T. R. H. (1991) South Africa. A Modern History, London, Macmillan.

Du Pisani T., Plekker S. J., Dennis C. R., Strauss J. P. (1991) Education and Manpower Development, no 11, Bloemfontein.

Farsakh L. (2015) Apartheid, Israel and Palestinian Statehood w: Israel and South Africa. The Many Faces of Apartheid, I. Pappé (red.), London, Publisher: Zed Books.

Giliomee H., Schlemmer L. (1989) From Apartheid to Nation-Building, Cape Town, Published by Oxford University Press.

Harber C. (1989) Politics in African Education, London, Macmillan.

Herman H. D. (1995) School-leaving Examinations, Selection and Equity in Higher Education in South Africa, "Comparative Education", 31 (2): 261-274.

Higgins J. i in. (2016) Academic Staffing w: South African Higher Education Reviewed. Two Decades of Democracy, Pretoria, Council on Higher Education.

Horrell M. (1963) African Education. Some Origins, and Development until 1953, Johannesburg, South African Institute of Race Relations. 
Horrell M. (1964) A Decade of Bantu Education, Johannesburg, Institute of Race Relations. South African Institute of Race Relations.

Horrell M. (1968) Bantu Education to 1968, Johannesburg, South African Institute of Race Relations.

Horrell M., Horner D., Hudson J. (1975) A Survey of Race Relations in South Africa, Johannesburg, South African Institute of Race Relations.

Johnson R. (1982) Education: Keystone of Apartheid, "Anthropology and Education Quarterly", 13 (3): 214-237.

Mabokela R. O. (2000) Voices of Conflict. Desegregating South African Universities, New York, Routledge.

Macquarrie J. W. (1960) Race and Education in South Africa, "The Phi Delta Kappan", $41(4)$.

Melosik Z. (1995) Wspótczesne amerykańskie spory edukacyjne. Między socjologiq edukacji a pedagogikq postmodernistycznq, Poznań, Wydawnictwo Naukowe Uniwersytetu im. Adama Mickiewicza.

Melosik Z. (2002) Uniwersytet i społeczeństwo. Dyskursy wolności, wiedzy i władzy, Poznań, Wydawnictwo Wolumin.

Mesthrie R. (2004) South Africa: a sociolinguistic overview w: Language in South Afri$c a$, R. Mesthrie (ed.), Cambridge, Cambridge University Press.

Moore R. (2004) Education and Society. Issues and Explanations in the Sociology of Education, Cambridge, Publisher: Polity.

Motala S. (1995) Surviving the System - a critical appraisal of some conventional wisdoms in primary education in South Africa, "Comparative Education", 31 (2).

Murphy R. (1988) Social Closure. The Theory of Monopolization and Exclusion, Oxford, Clarendon Press.

Parkin F. (1974) Strategies of Social Closure in Class Formation w: The Social Analysis of Class Structure, F. Parkin (ed.), London, Tavistock.

Parkin F. (1979) Marxism and Class Theory. A Bourgeois Critique, New York, Columbia University Press.

Sawisz A. (1987) Strategie i techniki wykluczania (kilka uwag na temat koncepcji «zamknięcia» w socjologii), „Studia Socjologiczne”, 3-4 (106-107). 
Smith R. D. (2000) Ecclesiastical Racism and the Politics of Confession in the United States and South Africa w: Race and Reconciliation in South Africa. A Multicultural Dialogue in Comparative Perspective, W. E. Van Vugt, G. D. Cloete (eds.), Lanham, Lexington Books.

Spaull N. (2013) Poverty and privilege: Primary school inequality in South Africa, "International Journal of Educational Development", 33 (5).

Śliwerski B. (2001) Program wychowawczy szkoły, Warszawa, Wydawnictwa Szkolne i Pedagogiczne.

Taylor N. (1989) Failing at the First Hurdle. Initial encounter with the formal system of African Education in South Africa, EPU Research Report, Johannesburg, Johannesburg, University of the Witwatersrand.

Tejani R. (2017) Professional apartheid: the racialization of US law schools after the global economic crisis, "American Ethnologist", 44 (3).

Tihanyi K. (2006) Blending in the Rainbow Nation. The Racial Integration of Schoolsand Its Implication for Reconciliation in Post-Apartheid South Africa, Lanham, Lexington Books.

Turner J. H. (2004) Struktura teorii socjologicznej, tłum J. Szmatka, Warszawa, Wydawnictwo Naukowe PWN.

Unterhalter E. (1991) Changing aspects of reformism in bantu education 1953-89 w: Apartheid Education and Popular Struggles, E. Unterhalter, H. Wolpe, T. Botha, S. Badat, T. Dlamini, B. Khotseng (eds.), London.

Van den Berghe P. L. (1966) Racial Segregation in South Africa: Degrees and Kinds, "Cahiers d'études africaines", 6 (23).

Van den Berghe P. L. (1967) Race and Racism. A Comparative Perspective, New York, Wiley \& Sons.

Wangenge-Ouma G. (2012) Tuition fees and the challenge of making higher education a popular commodity in South Africa, "Higher Education", 64 (2).

Weber M. (1968) Economy and Society. An Outline of Interpretive Sociology, G. Roth, C. Wittich (ed.), New York, Bedminster Press.

Welsh D. (2009) The Rise and Fall of Apartheid, Johannesburg, Jonathan Ball.

Wolpe H., Unterhalter E. (1991) Reproduction, reform and transformation: the analysis of education in South Africa w: Apartheid Education and Popular Struggles, E. Unterhalter, H. Wolpe, T. Botha, S. Badat, T. Dlamini, B. Khotseng (eds.), London, ZED. 